\title{
Rationality Conflict Between the Government and The Community: A Case Study on Illegal Gold Mining in Prabu Village, West Nusa Tenggara Province
}

\author{
Agus $^{1}$, Ida Hayu Dwimawanti ${ }^{2}$ \\ \{ida2hade@gmail.com ${ }^{2}$ \} \\ Universitas Diponegoro, Indonesia ${ }^{1,2}$
}

\begin{abstract}
This paper discusses the phenomenon of illegal gold mining in Prabu Village, Central Lombok Regency, West Nusa Tenggara, using the theory of the impact of the use of mercury, rational choice theory, and the role of local government theory. The use of mercury in mining endangers health and destroys the environment. Since the mining activities are still occurring, the role of regency government in preventing living environmental damage is still not effective. It is suggested that provincial government closes down the mine.
\end{abstract}

Keywords: Illegal mining, Impact, Rationality, Local Government.

\section{Introduction}

Central Lombok is one of the nine regencies and cities in West Nusa Tenggara Province. The regency consists of 12 districts, out of which is Pujut, which is the district with the widest area. The strategic policy implemented by the local government is tourism-based area development. This strategic policy is thus in line with the establishment of Mandalika as Special Economic Zone by the government.

Indonesia is a country with overflowing natural resources. Apart from being wide, the country consists of islands. Thus, at this time, the right governing management is is decentralization. It is hoped that this will foster initiative and the role of local government in accelerating public welfare. This concept is stated as the objective of local government regulation in Law number 23 Year 2014 about Local Government [1]. The Law firmly states that the implementation of local government is directed to accelerate the realization of public welfare through service improvement, community empowerment and participation, as well as the enhancement of the regions' competitiveness by taking into account the principles of democracy, equality, justice, and the peculiarities of a region within the Unitary State of Republic of Indonesia.

Public welfare and living environment sustainability, which are supposed to be synergized, are not always easily manifested. The government's policy to accelerate public welfare, or the public's desire to be prosperous faster, if not controlled, will result in the destruction of living environment. As a prevention, Local Government Laws grant the regency/ city government the authority to do prevention, counter measurement, and control on the contamination of living environment. 
The public's activity of mining gold illegally occurs in a lot of places. One of them takes place in the area of Prabu Mountain in Prabu Village Pujut District, Central Lombok. This illegal gold mine locus is around $5 \mathrm{kms}$ away from Mandalika Special Economic Zone that is the region's main tourism area. In the midst of Central Government's commitment of realizing Mandalika Special Economic Zone as World Tourism Destination, the public, on the other hand, is doing illegal gold mining, which at this point has put enough danger on the environment destruction.

A couple of studies regarding illegal mining by public community show negative impacts. The mining does not only impose negative impact on the sustainability of living environment, but also on the health of the miners. Even so, the policy to stop illegal mining which has long been going on is not a simple matter. A study conducted by Siregar [2] regarding the dispute of mechanical sand mining in Brantas River, Jongbiru Village in Kediri Regency shows two important data. First, sand miner is an occupation which has long been entrenched in the community who lives around Brantas river watershed, especially Jongbiru villagers. Second, if a ban for the existence of manual and traditional sand mine must be established, the government will then be urged to provide other job alternatives so that people will not lose their jobs. Thus, the local government didn't close the Brantas River illegal sand mine because they didn't want to have a conflict with the public community.

However, there is also the case whereby the public does illegal mining because of their unawareness of the impact it causes. This phenomenon is shown in a study conducted by Mariani et al [3] regarding the information about the impacts of sand mining on living environment destruction among illegal sand miners in Jeneberang Village, Goa Regency. The result of the study shows that illegal mining occurs due to the lack of illegal miners' awareness about the impact of mining on living environment. Although local government has held socialization regarding this matter, the socialization conducted by Goa Regency's Local Environmental Agency hadn't been able to reach all of the public.

Even though there have been a lot of instances showing that illegal mining destroys living environment and harms the surrounding local community, the phenomenon of illegal mining is still occurring in some areas, one of which is in Central Lombok. The questions proposed in this discussion are thus as follows: why does the local community still conduct illegal mining, and what are the roles of the local government in preventing it?

In order to conduct an analysis on the community's reasoning, this paper uses two different theories, namely rational choice theory, and local government's role theory. The first theory is meant to capture the miners' as well as the local government's rationality, while the second theory is used to conduct an analysis on the provincial and regency's government's authority on mining and living environment sector.

Rational choice theory was brought into popularity by James S. Coleman from Harvard University through his book, Foundation of Social Theory, in 1994. According to Coleman in Ritzer and Godman [4], there are two main elements of rational choice, namely, actors and resources. Resources are everything which attracts and can be controlled by actors. Coleman explains that the interaction between actors and resources in details are as follows:

"The minimum base for an action is two actors, each of whom controls a resource which attracts the attention of the other party. The person's attention on the resource controlled by the other person is what causes the two to be involved in an interdependent action... are involved in a system of action. As an actor, he has an objective, that is to maximize the manifestation of his interest, which gives the characteristic of interdependence, or systemic characteristic on their action. 
Coleman's understanding above confirms that a resource is human action's main instrument in achieving the objective related to the actor's interest. This thought of Coleman was influenced by Max Weber when he explained about social action epistemology. In his theory about social action, Weber asserts the term social action as human's behaviour when and as far as the agent or agents see it as something subjectively meaningful. Weber stated that all individuals inherently own action orientation. The task of a policy analyst is interpreting human's action orientation. In Michel M. Harmon and Richard T. Mayer's work [5], Weber divides human's action orientation hierarchically into four types, namely:

a) Traditional, which is the most basic action orientation. That is, the action which is originated from habits. This action is done many times in daily life.

b) Affectual, which is an action determined by emotions, feelings, and the expression of the actor's feeling.

c) Value-rational (wert rational), which is an action done consciously by a belief in a specific value for the sake of that value itself.

d) Instrumental-rational (zweckrational), which is an action done after previously calculating and considering its meaning, purpose, and consequences.

Weber's view is further reinforced by Fischer, Miller, and Sidney [6]. They mention the basic assumption proposed by rationality theory, that is: an individual is characterized as an instrumental actor, and various actions are narrowed as 'done not for the sake of said action, but merely as far as the action guarantees the desired objective, which is normally a private matter.

Even though illegal gold mining in Prabu Village is the community's source of employement, so that the public commit illegal mining to fulfill their necessities of life, in order not to destroy living environment, the local government carried out prevention with various programs. The local government's failure in preventing the damage is caused by a number of obstacles.

The theory of local government's role was introduced by Leach, Stewarth, and Walsh. In Khaerul Muluk [7], it was mentioned that they map three factors which influence the role of local government, of which they later addressed as three dimensions, namely; economic dimension, the dimension of the government, and political dimension associated with a form of local democracy.

The first dimension is related to the sources of public service provision, which include both production and the distribution of commodity and service at local level. The dimensions of the government differentiate weak from strong role of local government. The weak role of local government is characterized by the narrow range of functional responsibilities or authorities, the execution of government which are reactive in nature, the low degree of autonomy over the functions borne, and a high degree of external control. Meanwhile, a strong role of local government is characterized by a wide range of functional responsibilities or authority, a positive execution of local government, a high degree of autonomy over the functions borne, and limited degree of external control.

Political dimensions which are related to local democracy are reflected in how local government makes a decision. There are two different sides of this matter. On one side, there is an emphasis on representative democracy, that is, a system which reflects the community's preference that has been stated through election. On the other side, there is an emphasis on participatory democracy, which reflects the local community's participation. This participatory democracy is run in democracy forums which are viewed as an essential composition in the making of decision in the region. 


\section{Research Method}

This research uses qualitative method with case study approach. That is, a study was conducted to explore the case of illegal gold mining in Prabu Village, Central Lombok. The choice of case study approach model is supported by Creswell [8]. The reason case study was chosen is because the study aims to elaborate the issues surrounding the impact of illegal gold mining, and to discover the problems which cause the government, up to this day, has yet to close down the mine. The informant selection technique used is purposive sampling, that is, choosing the sample by considering the informants' mastery of the information needed. This method is supported by Ahmad [9].

Data analysis was conducted using deductive-qualitative approach. According to Bungin [10] deductive-qualitative analysis model analyses the surface of the data more, and pays attention to the process of how a phenomenon occurs, instead of focusing on the depth or the meaning of the data. As for the research data analysis procedures, the procedures are as follows; (1) finding the domain for the research analysis; (2) mapping the domain of the analysis, whether it is single domain or double domain; (3) if single, then arranging a description based on vertical or horizontal phenomena; (4) drawing conclusion as findings based on the description.

\section{Result and Discussion}

\subsection{The history of Prabu Village's Illegal Gold Mining}

Prabu Village is one of the 16 villages in Pujuk District, Central Lombok. According to data from Central Bureau of Statistics (10), Prabu village has a population of 3,973, consisting of 1,976 males and 2,047 females. Economically, Prabu Village is a village supporting the development of Special Economic Zone Mandalika project.

Initially, the activity of illegal gold mining occured in Sekotong Village, West Lombok Regency. However, after environmental damage has occured in Sekotong, the activity relocates to Prabu Village in Central Lombok since 2011. That was the information obtained from the Head of Infrastructure and Region Division of Central Lombok Regional Development Planning Agency. This explanation is further reinforced by the study conducted by Yusa and Rukmi [11]. This gold mining is considered illegal because the mining activities doesn't have a permit from local government. The rocks which were unearthed contains gold, which are then taken to rock processing sites scattered around some districts in Central Lombok Regency. The district with the highest number of gold rock processors is Pringgarata District.

Based on the information retrieved from Central Lombok Regency's Local Environmental Agency, illegal gold processing is conducted through two techniques, namely amalgamation (spindle) and cyanidation (barrel). It is not only the gold produced from gold amalgation process which can be used as a commodity, tailings, which are the waste from the amalgation process that still contain gold are also sold to undergo further processing to obtain scrap metal that is still in the tailing taking the form of liquid in room temperature of 25 degree celcius with the lowest freezing point of around 30 degree celcius. 


\subsection{The Impact of Mercury on Environment}

The use of mercury in mining occurs in almost all of illegal gold minings. One instance of this is the case of illegal gold mining in Peru, in which the use of mercury has far damaged the living environment. Alina Buccella's research result shows that if no action is to be done to stop the use of mercury in public's gold mining, thousands of people might suffer from mercury pollution [12].

According to Sitepu [13], mercury or hydrargyrum is one of the metal which takes the form of liquid. It is silver in color, with the symbol $\mathrm{Hg}$ (hydrargyrum) and atomic number 80 . In addition, it has the atomic weight of 200.59. Generally, the characteristics of mercury are as follows; (1) takes the form of liquid at room temperature of 25 degree celcius, with the lowest freezing point of around 39 degree celcius; (2) at the temperature of 396 degree celcius, has expanded thoroughly (3) is the most volatile metal compared to the other metals; (4) has an extremely low electrical resistivity, which places mercury as an excellent metal to conduct electricity; (5) can dissolve various metals to form alloy, also called amalgam.

The impact of mercury on environmental damage in the cases of illegal mining is also supported by Prianto \& Husnah's research [14]. Through the research entitled 'Inconventional Tin Mining: Its impact on the destruction of Bangka Island waters' biodeversity' they figured that the illegal mining which had been occurring since 2000 had given a horrible impact on aquatic ecosystem, such as; (1) sedimentation and changes in coastal area landscape; (2) increase in the fertility of the waters; (3) increase in the waters' turbidity; (4) the destruction of ecosystem and the extinction of aquatic biota; and (5) heavy metal pollution. It is feared that this inconventional tin mining case could become an iceberg phenomenon which one day could become a horizontal conflict among fellow citizens.

Mercury is an extremely toxic element for all living creatures, whether it is in the form of single element (metal), or in compound form. The toxicity of mercury in human depends on the form, the composition of the mercury, the route from which it enters the body, and the length of exposure. Around $99 \%$ of organic form of mercury such as methylmercury is absorbed by the wall of intestine. This is far greater than its inorganic form (HGC12), of which only around $10 \%$ is absorbed. However, this organic mercury form is less corrosive than its inorganic form.

Prabu Village's illegal gold mining has been using mercury since the mining started to be done in 2011. Nowadays, the impact of the use of mercury towards the contamination of living environment has widespread. The living environmental damage in Prabu village does not only bother the local government, but also the executants of the tourism industry, who are investing in Mandalika Special Economic Zone. The government and the executants of the tourism industry's concerns are due to the pretty significant resistance of the tourism's living environmental damage.

\subsection{Conflicts between the Government's and the Communities' Rationality}

By using Rational Choice Theory to analyze illegal gold mining phenomenon in Prabu Village in Central Lombok Regency, West Nusa Tenggara, several facts are discovered. Illegal gold mining phenomenon which has long been occurring in Prabu Village when this paper is composed puts the government, businessmen, tourism activists, and the communities on the horns of a dilemma. Those actors have the same perception, that is, illegal gold mining activities are damaging to the safety of the environment. Up to this point, the community has felt the impacts of this illegal mining, including landslide, difficulties in finding agricultural 
land, difficulties in finding animal feed, and difficulties in finding clean water. Businessmen and tourism activists receive complaints from tourists because Prabu Village as a road connecting two tourism destinations, Kuta and Selong Belanak, is getting uncomfortable. Rock ruins and soil of former mining areas are found along the road connecting those two tourism destinations. This condition jeopardizes the tourists' safety, because the soil from the landslide heading to the road is making the road slippery. The local government has been receiving criticism from the public, and has been put into the spotlight by mass media, as well as other civil society for the past three years.

On the other hand, the government and the community have different rationality. Later, these different rationalities result in conflicts between the two. As explained by Coleman in the introduction section, there are two main elements of rational choice, namely actors and resources. Furthermore, Coleman states that resources are the main instruments of human action in achieving objectives that match the actors' interest. The interest of the community as an actor is economical interest. From economic aspect point of view, the people of Prabu village are characterized by a fairly high level of structural poverty. This area is a barren area, with rainfed agriculture where the people can plant crops once a year. Agriculture, as the people's sole commodity does not appear to be well developed. This condition causes the people to experience limited access to education, health, and houses. The presence of businessmen who give the community a job to mine the hill in Prabu village to get gold is perceived as a way out of poverty by the local community. Therefore, economic interest becomes the basis of people's rationality in maintaining their mining activities up to this day.

Coleman's model of economic rationality is supported by Weber's model's perspective of human action's orientation. As elaborated in the introduction section, Weber divides human's action orientation hierarchically into four types, namely: traditional, affectual, valuerational, and instrumental-rational. Initially, the community's activity. Initially, the people's illegal mining activities were supported by the culture of the local community that was apathetic to environmental sustainability. They are accustomed to littering and digging rocks around them. The lack of education about environmental sustainability results in these behaviors of the people's becoming habits. This stage is traditional actions. Difficulties in finding jobs then cause people to vent their angers through mining activities even though it is illegal. The community does not care about the prohibition from local government because they perceive the local government as incapable of providing jobs for them. The action at this stage is included as affectual action. As the time during which the people earn quite good amount of money through mining activities passed, the community then perceive their jobs to mine gold illegally as a force on economic value, or also called as rational value. Currently, illegal gold mining activities in Prabu Village have become the community's instrumental rationality, that is, the people's main occupation.

On the community's instrumental rationality stage, Local government is facing difficulties in stopping mining activity, even though it has come to the point where it damages the environment. According to an informant from Local Government of Central Lombok Regency, the government, through socialization programs, has attempted to explain to the community about mine worker relocations. Hence, people don't lose their jobs. Government of Central Lombok Regency planned to relocate the miners to Mandalika Special Economic Zone. Therefore, the people will not lose their jobs, as some people worried about. However, the community was not willing to accept regency government's offer because they were worried that Mandalika Special Economic Zone requires skilled workers in tourism sector. They were also worried about the fact that Mandalika Special Economic Zone is an authority ruled by the central government and developed by Pt. Indonesian Tourism Development 
Corporation (ITDC), not by regency government. This anxiety of people has apparently been unable to be accounted for by The Government of Central Lombok Regency.

Rationality conflicts between provincial and regency government also continue to occur among regional government actors. Each actor based their rationality on normative rationality, which is based on the authority given by the Law. By using Local Government's Role theory as described in the introduction section, it was discovered that there exist conflicts of authority between Provincial and Regency Government regarding mining affairs. The provision governed in Law number 23 Year 2014 as amended by Law number 9 of 2015 regarding government states that gold mining is provincial government's concern [1]. Consequently, Prabu Village's illegal gold mining's shutdown is regarded as the authority of provincial government. However, prevention of the living environment contamination is regency government's concern. Based on that provision, the provincial government encourages regency government to quickly resolve the prevention of living environmental damage which occurs in Prabu Village. This results in the public's assigning the living environmental damage in Prabu Village as the regency government's fault. Meanwhile, the regency government stated that as long as the illegal mining has yet to be closed by the Provincial Government, the environmental damage prevention program in Prabu Village will not be effective.

Prevention of environmental damage in tourism destination areas which are located in Central Lombok Regency, especially in the southern region, has been regulated by the regional government through Central Lombok's Regional Regulation Number 7 of 2011 on Regional Spatial Planning of Central Lombok Regency Year 2011-2023 [15]. Article 6 letter c of the regulation mentions that 'the development and stabilization of coastal and marine areas are to encourage investment, transportation, and the saving of environment'. This narrative indicates that Central Lombok's regional spatial plan does not acknowledge mining activities, especially in the area of Pujut District, which is a tourism area (Article 30 paragraph 1). Supposedly, in making a policy for a locus located in the regency area, Provincial Government of West Nusa Tenggara should consider the Regency's Regional Regulations. It is so that the region's or the city's spatial planning and layouts are in line with the provincial and central government programs. Apart from that, the people can also obtain a certainty about the allocation of space.

From all the description above, it appears that the problem of illegal gold mining which continues to occur until it damages the environment stems from conflicts between the government's and the community's rationality regarding the meaning of gold mining. Poverty and limited job opportunities become pragmatic rationality for mining activities conducted by the community. Meanwhile, normative rationality, namely conflicts of authority between Provincial and Regency government, becomes Local Government's administrative and political rationality. Thus, it can be predicted that as long as this rationality conflicts cannot be resolved, it will be difficult to overcome illegal gold mining activities in Prabu Village. Subsequently, the solution offered is a meeting between the three actors, namely Provincial Government of West Nusa Tenggara, Regency Government of Central Lombok, and the community. Together, these three actors need to formulate a solution that does not harm one another, particularly, a solution that does not harm and disturb the people's sense of justice, while surely also does not allow continuous environmental damage. 


\section{Conclusion}

Apart from resulting in the contamination of living environment, illegal gold mining in Prabu Village Central Lombok Regency which has been occurring since 2011 also threatens the continuity of tourism development. On one hand, referring to long term-regional development plan and medium term-regional development plan, tourism is a priority in Central Lombok Regency development. Tourism object which is affected the most from Prabu Village's illegal gold mining is Mandalika Special Economic Zone, because Prabu village is one of the supporting villages for the Special Economic Zone. Environmental damage increasingly spreads because the miners use mercury.

The illegal gold mine shutdown is hindered by several factors, that is, the people have already viewed the activities in mine site as their livelihood, the growth of informal elites which receive economical profit from mining activities, and the overlapping authorities of the local governments. In the local government law, gold mining is provincial government's authority, while regency government only holds the authority to prevent living environmental damage. Although the prevention of environmental damage has been conducted by regency government through socialization and the involvement of civil society, environmental damage continues to occur because illegal mining activities by the local communities are not shut down by provincial government.

From the description above, this paper recommends the need for a quick response from West Nusa Tenggara Provincial Government to stop illegal gold mining activity by public. Apart from saving miners from the danger of mercury, this policy is also required to support the sustainability of tourism sector as the region's development priority.

\section{References}

[1] "Law of the republic of Indonesia Number 23 Year 2014 on Local Government.".

[2] G. V. A. Siregar, "Brantas River Mechanical Sand Mining Dispute: A study on the Legal dispute of the Mechanical Sand Mining Activity in Jongbiru Village, Gampengrejo District, Kediri Regency, Bioculture," vol. 1, no. 2, p. 196, 2012.

[3] and I. S. Mariani, Sumbangan Baja, "Information regarding the impact of sand mining on living environmental damage among illegal sand miners in Das Jeneberang, Goa Regency," KAREBA J. Commun., vol. 3, no. 2, pp. 112-118, 2014.

[4] D. J. Ritzer, George \& Goodman, Modern Sociology Theory. Jakarta: Prenada Media, 2004.

[5] M. M. Harmon and R. T. Mayer, Organization theory for public administration. Boston: Little, Brown, 1986.

[6] F. Fischer and G. J. Miller, Handbook of public policy analysis: theory, politics, and methods. Routledge, 2017.

[7] K. Muluk, Decentralization and Local Government Concept Map. Surabaya: ITPS Press, 2009.

[8] J. W. Creswell and C. N. Poth, Qualitative inquiry and research design: Choosing among five approaches. Sage publications, 2016.

[9] A. Jamaluddin, Public Administration Research Method: Theory and Application. Gava Media, 2015.

[10] B. Bungin, "Qualitative Research: Communication, Economics," Public Policy, Other Soc. Sci. Jakarta Kencana, 2007.

[11] M. M. \& L. R. Yusa, "2D Educational Video regarding the Danger of Mercury on Central Lombok Regency People as the Impact of Illegal Gold Mining," Andharupa, vol. 3, no. 2, pp. 176-195, 20017.

[12] A. Buccella, "Can the Minamata Convention on Mercury Solve Peru's Illegal Artisanal Gold 
Mining Problem?," Yearb. Int. Environ. Law, vol. 24, no. 1, pp. 166-187, 2014.

[13] M. Sitepu, "Mercury and its Dangers on Health," vol. 5, no. 4, 20014.

[14] E. P. \& Husnah, "Inconventional Tin Mining: Its impact on the destruction of Bangka Island waters," J. BAWAL, vol. 2, no. 5, pp. 193-198, 20009.

[15] "Central Lombok's Regional Regulation Number 7 Year 2011 on Regional Spatial Planning of Central Lombok Regency Year 2011 - 2023.”. 